2010

\title{
LIQUID-IIQUID EXTRACTION OF AMERICIUM FROM MOLTEN PLUTONIUM METAL
}

\author{
J. D. Moseley \\ J. B. Knighton
}

August 4, 1972

Chemistry Research and Development Process Chemistry

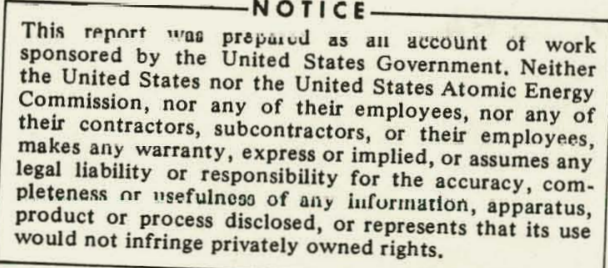

would not infringe privately owned rights. 


\section{DISCLAIMER}

This report was prepared as an account of work sponsored by an agency of the United States Government. Neither the United States Government nor any agency Thereof, nor any of their employees, makes any warranty, express or implied, or assumes any legal liability or responsibility for the accuracy, completeness, or usefulness of any information, apparatus, product, or process disclosed, or represents that its use would not infringe privately owned rights. Reference herein to any specific commercial product, process, or service by trade name, trademark, manufacturer, or otherwise does not necessarily constitute or imply its endorsement, recommendation, or favoring by the United States Government or any agency thereof. The views and opinions of authors expressed herein do not necessarily state or reflect those of the United States Government or any agency thereof. 


\section{DISCLAIMER}

Portions of this document may be illegible in electronic image products. Images are produced from the best available original document. 


\section{INTRODUCTION}

Dow Chemical U.S.A. operates the Rocky Flats facility for the United States Atomic Energy Commission. A principal product of the Chemical Operations section is highly pure plutonium metal. One of the principal impurities of plutonium that requires periodic removal is americium, which grows into the metal during long-term storage by the beta decay of the 241 isotope, of plutonium. There are metallurgical reasons - hete necessitating the removal of the americium but our primary motivation is to reduce the radiation exposure to personnel working with the materials after they leave the chemical purification area. The radiation exposure problem is due to americium-241 emitting penetrating gamma ray radiation that is difficult to shield against. Yet another motivation for the separation and purification of americium is that it serves as a target material in the nuclear reactor. syntliesia of plutonium-238, which is used for a variety of scientific, space exploration and medical púrposes.

\section{PROCESS DESCRIPTION}

The process is quite simple. Molten plutonium metal is equilibrated with a molten salt and the americium is preferentially extracted into the salt. This is accomplished 
within a conventional glovebox held at a slight vacuum due to the toxicity of the actinide metals. The plutonium metal is placed inside a tantalum crucible, a salt cake is placed in the crucible, and the crucible is placed in a pot furnace. The furnace is closed, evacuated, and filled with argon at a slight overpressure. This slight argon overpressure is maintained during the course of the run to inhibit oxidation of the plutonium and the tantalum. The furnace contents are beated to about $750^{\circ} \mathrm{C}$ (approximately $100^{\circ} \mathrm{C}$ above the melting point of the contents) and stirred to achieve rapid equilibration. The stirrer is lifted from the melt and the furnace allowed to cool. The americium-depleted plutonium metal and the salt containing americium and some plutonium are then separated. The salt solvent commonly used is the NaCl-50 mole $\% \mathrm{KCl}$ eutectic composition. To this one may add plutonium trichloride, one of the plutonium fluorides, or magnesium chloride to act as an oxidant in the reaction shown on Slide 1 . We choose to use magnesium chloride due to relative ease of material handling.

\section{THERMODYNAMIC BASIS FOR EXTRACTION}

The standard free energies of formation reported for several elements of interest are shown on Slide 2 . 


\section{SLIDE 1}

$$
\mathrm{Am}^{0}+3 / \mathrm{XM} \mathrm{M}^{\mathrm{X}} \rightarrow \mathrm{Am}^{+3}+3 / 2 \mathrm{M}^{0}
$$

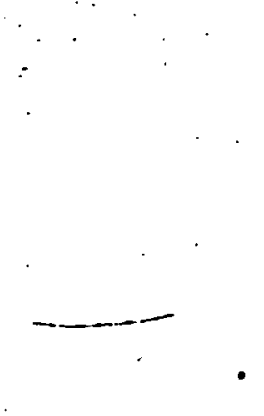




\section{SLIDE 2}

STANDARD FREE ENERGIES OF FORMATION OF SELECTED CHLORIDES IN ORDER OF INCREASING STABILITY AT $1000^{\circ} \mathrm{K} *$

\begin{tabular}{lc} 
Compound & \multicolumn{2}{c}{$-\Delta \mathrm{G}^{\circ}$} \\
$\mathrm{MgCl}_{2}$ & 58 \\
$\mathrm{PuCl}_{3}$ & 66 \\
$\mathrm{CeCl}_{3}$ & 67 \\
$\mathrm{AmCl}_{3}$ & 76 \\
$\mathrm{NaCl}$ & 82 \\
$\mathrm{KCl}$ & \\
\hline${ }^{*} \mathrm{Glassner,} A .$, USAEC Report
\end{tabular}
ANL-5750. 
From the relationship $-\Delta G=R T$ InK and with the assumption that allactivity coefficients are unity, it is seen that the ratio shown on slide 3 should equal about $10^{5}$. In fact, the ratio obtained in an extended series of equilibrations is about $10^{3}$ less than this, or about $3( \pm 0.5) \times 10^{2}$. It is generally believed that the reported $\Delta G$ value for $\mathrm{AmCl}_{3}$ is in error by about $5 \mathrm{kcal} / \mathrm{g}$ atom $\mathrm{Cl}$. Observations of the analogous ratio for cerium are in agreement with the theoretical values. Efforts are being made to more precisely determine the correct thermodynamic values.

\section{EXTRACTION COEFFICIENTS}

In countercurrent extraction processes, our present mode of operation, the salt and metal solvents move countercurrent to each other through the extraction stages as shown in Slide 4.

The fraction of a solute partitioning to each phase may be expressed using the extraction factors as shown on slide 4. We have found it convenient to operate a two-stage process and to operate with an $f_{S}$ overall of 0.9 . Our extraction factor must therefore be 2.5 or greater for our particular operating conditions.

The extraction faclü is defined on side 5 . 


\section{SLIDE 3}

$$
K=\frac{p p m A m^{*} \text { in salt }}{\text { ppmAm* in metal }} \approx 10^{5}
$$

*parts of americium per million parts of plutonium. 
SLIDE 4

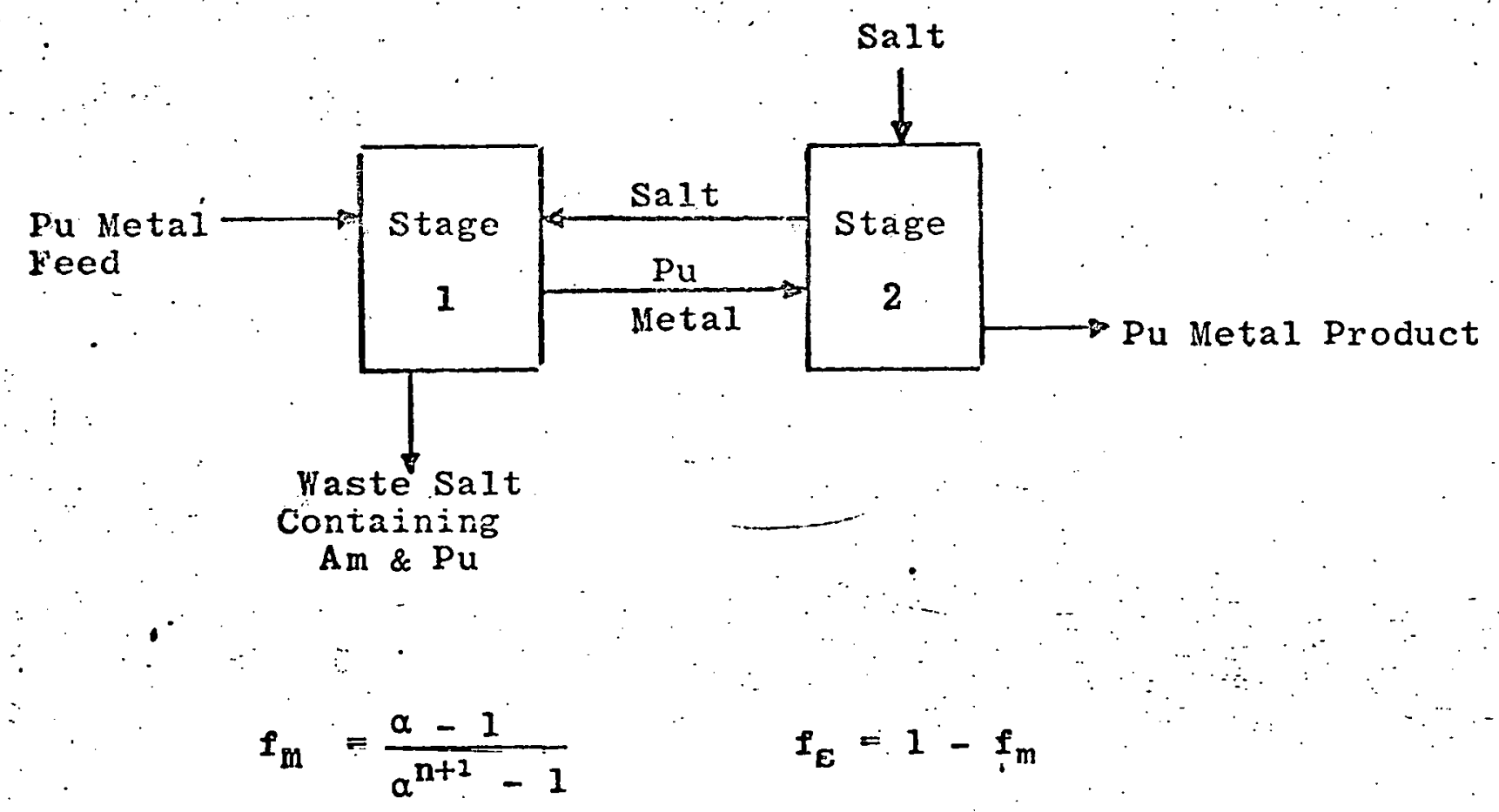

$$
\begin{aligned}
& \text { i) number of stages } \\
& \alpha=\text { extraction factor }
\end{aligned}
$$




\section{SI. IDE 5}

$$
\begin{aligned}
\alpha_{\mathrm{Am}} & =\left(\mathrm{K}_{\mathrm{d}_{\mathrm{Am}}}\right) \times(\mathrm{s} / \mathrm{m}) \times(\mathrm{F}) \\
a_{\mathrm{Am}} & =\text { americium extraction factor } \\
\mathrm{K}_{\mathrm{d}_{\mathrm{Am}}} & =\text { equilibrium distribution } \\
& =\frac{\text { Am in salt }(w t \%)}{\text { Am in metal (wt } \%)} \\
\mathbf{s} / \mathrm{m} & =\text { salt to metal weight ratio } \\
& =\text { soivent } 2 / \text { solvent } i \\
\mathrm{~F} & =\text { fraction of equilibrium }
\end{aligned}
$$


Assuming the achievement of equilibrium, it is seen that we have two variables--(Kd Am), a function of $\mathrm{MgCl}_{2}$ content-and $(\mathrm{s} / \mathrm{m})$ a matter of choice and/or equipment design (within Iimits)

Johnson at the Argonne National Laboratory has reported a relationship for these types of systems, shown on slide 6 , and has shown its utility for a number of fission product rare earths and for some actinides.

Using data points from 0 to 30 mole $\% \mathrm{MgCl}_{2}$ and extrapolating beyond using Johnson's relationship, we have obtained the distribution coefficient plot as a function of $\mathrm{MgCl}_{2}$ content in the solvent salt ( $\mathrm{NaCl}-\mathrm{KCl}$ equimolar) shown on slide 7 .

From this plot, and based on equipment configurations, we operate with a $\mathrm{s} / \mathrm{m}$ of 0.65 , and a $\mathrm{MgCl}_{2}$ content of 6 mole \%.

The, molten salt extraction of americium from plutonium metal is en a production process at the Rocky Flats facility,

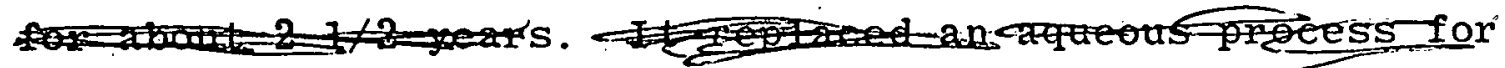

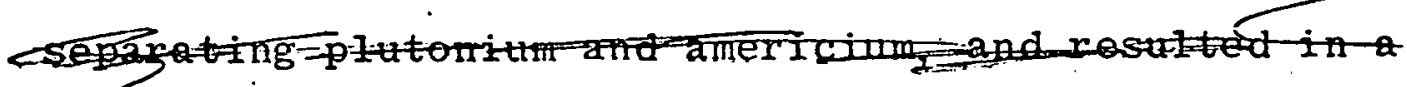

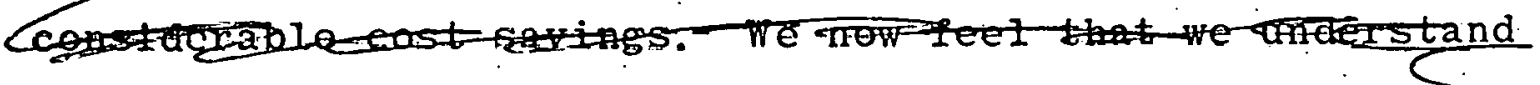

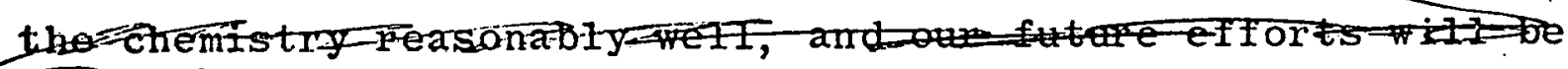

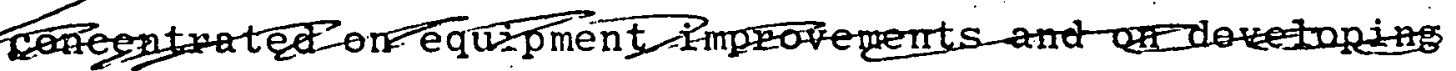

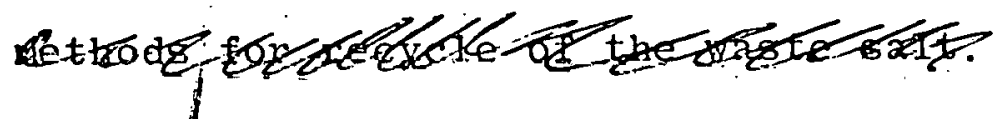




\section{SLIDE 6}

$$
\begin{aligned}
& \mathrm{K}_{\mathrm{d}}=\mathrm{c}\left(\mathrm{MgCl}_{2}\right)^{3 / 2} \\
& \mathbf{k}_{\mathbf{d}}=\text { equilibrium distribution }
\end{aligned}
$$$$
\text { c }=\underbrace{\text { constant for a solvent }}_{\text {system }}
$$

$\left(\mathrm{MgCl}_{2}\right)=$ mole fraction of $\mathrm{MgCl}_{2}$

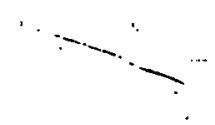


SLIDE 7

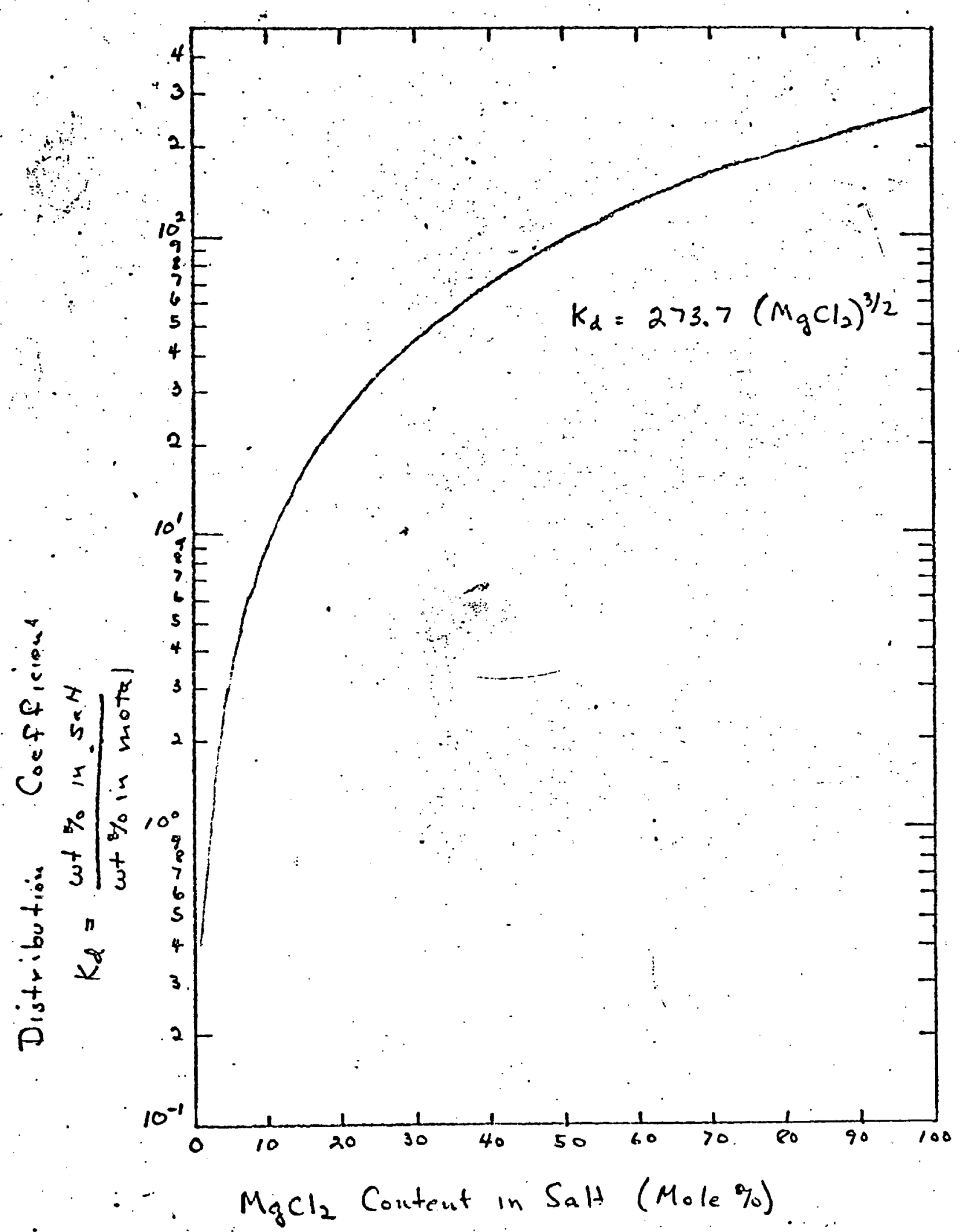

Distribution of Amerianim between Naci-kel- $\mathrm{Mej}_{2}$ Salt (Soljout 2) and Plutanin. (Soluout 1) $-12-$ 